Summer 2010

\title{
It's a Pirate's Life for Some: The Development of an Illegal Industry in Response to an Unjust Global Power Dynamic
}

\author{
Elliot A. Anderson \\ Indiana University Maurer School of Law
}

Follow this and additional works at: https://www.repository.law.indiana.edu/ijgls

Part of the International Law Commons, and the Law of the Sea Commons

\section{Recommended Citation}

Anderson, Elliot A. (2010) "It's a Pirate's Life for Some: The Development of an Illegal Industry in Response to an Unjust Global Power Dynamic," Indiana Journal of Global Legal Studies: Vol. 17 : Iss. 2 , Article 9.

Available at: https://www.repository.law.indiana.edu/ijgls/vol17/iss2/9

This Note is brought to you for free and open access by the Law School Journals at Digital Repository @ Maurer Law. It has been accepted for inclusion in Indiana Journal of Global Legal Studies by an authorized editor of Digital Repository @ Maurer Law. For more information, please contact rvaughan@indiana.edu.

\section{$\Psi$}

JEROME HALL LAW LIBRARY

INDIANA UNIVERSITY

Maurer School of Law
Bloomingeton 


\title{
It's a Pirate's Life for Some: The Development of an Illegal Industry in Response to an Unjust Global Power Dynamic
}

\author{
ELLIOT A. ANDERSON ${ }^{*}$
}

\begin{abstract}
This Note discusses the domestic and international economic effects of the recent surge of piracy off the coast of Somalia, and uses Somali piracy as a method of exploring conflicting ideological conditions that arise from globalization. In exploring the underlying motivations for this trend, it identifies a dichotomy between primary needs satisfaction within underdeveloped nations and the satisfaction of secondary interests in developed nations, and explains how globalization may be exacerbating the turn toward piracy. This Note first discusses the recent rise in piracy and then explores how the contemporary history of Somalia has engendered the upsurge. Next, it considers how piracy has influenced the economy of coastal Somalia, followed by a look at the ideological intersection between primary domestic interests and secondary global interests. Finally, this Note explores some of the international implications of the rise of piracy in Africa, and whether further expansion is a possibility.
\end{abstract}

\section{INTRODUCTION}

Whether a surge in an illicit domestic industry represents a turn in the international power structure that is engendered by globalization is a formidable question. One issue that may arise in an international conflict is the ideological polarization between developed and underdeveloped nations that stems from the desire for basic needs satisfaction. As nations either develop, or remain developmentally stagnant, those who reside within them have interests tied to-among

* Notes Editor, Indiana Journal of Global Legal Studies; J.D. Candidate, 2010, Indiana University Maurer School of Law.

Indiana Journal of Global Legal Studies Vol. 17 \#2 (Summer 2010)

(C) Indiana University Maurer School of Law

DOI: $10.2979 /$ GLS.2010.17.2.319 
other things-fulfilling their particular basic needs such as food and shelter. In nations in which people are better able to satisfy their basic needs, individuals may identify secondary interests, such as industry and trade, the pursuance of which may conflict with the enduring concerns of those in lesser developed nations whose goal remains limited to receiving what they need to survive.

This clash between those satisfying their society's secondary interests and those simply trying to survive by fulfilling their basic needs can polarize an international community whose members pursue self-serving ends through almost any means. Developmentally challenged nations that find themselves in this situation run the risk of falling prey to their more self-sufficient and accomplished international neighbors. For the sake of self-preservation, citizens in the weaker nation will sometimes act out of desperation, resorting to illegal activities to obtain basic necessities while disregarding the international response to their actions.

Domestic degradation is not always the result of mere internal political or economic strife, nor social dissatisfaction. Maritime piracy off the coast of Somalia is evidence that a combination of domestic factors coupled with the negligence of the international community can actually exacerbate domestic incapability to the extent that it becomes an international criminal incident with serious global significance.

The United Nations Convention on the Law of the Sea (UNCLOS) defines piracy as "any illegal acts of violence or detention or any act of depredation, committed for private ends by the crew or the passengers of a private ship," and is limited to the high seas and places "outside the jurisdiction of any State." Because piracy is considered to be a violation of the law of nations, any nation's public vessel has the authority to seize a pirate ship and try those responsible for the crime. ${ }^{2}$ This thriving but illegal industry implicates both domestic and international efforts at national building. The rise of piracy exhibits the importance of the international effort to assist in nation building and therefore to help create domestic stability, so as to avoid such industries taking hold in underdeveloped regions. Maritime piracy represents a real danger that nations face through increasing globalization. The purpose of this Note is to discuss how piracy can be a reflective microcosm of the exploitation of an unfair global power dynamic that helps encourage criminal behavior through a failure to self-regulate from a legal perspective.

1. United Nations Convention on the Law of the Sea art. 101, Dec. 10, 1982, 1833 U.N.T.S. 3 [hereinafter UNCLOS].

2. Id. art. 105 . 
Over the last decade, the number of maritime piracy attacks has increased steadily, and more recently, that number has skyrocketed. ${ }^{3}$ During 2008, a worldwide total of 293 reported incidents of piracy occurred against ships, an increase of eleven percent from $2007 .^{4}$ In 2009, 406 incidents were reported, marking the third successive year this number has increased and the largest percent increase on record. ${ }^{5}$ Incidents of piracy include attacks, robberies, and hijacks on vessels that are either out at sea or in port. ${ }^{6}$ Prior to 1992 , statistics that suggested trends in attack frequency were difficult to accumulate because no standard method for incident reporting was in place. ${ }^{7}$ But, in 1992, the International Maritime Bureau (IMB), one of the International Chamber of Commerce's Commercial Crime Services, established the Piracy Reporting Centre, which enabled shipmasters to report actual or attempted attacks against vessels. ${ }^{8}$ The development of this system helped to raise awareness of areas that were particularly risky to the shipping industry. ${ }^{9}$ Recently, a glance at the IMB's live piracy map displays a very clear area of exceptionally high risk to the industry. ${ }^{10}$

The region on the eastern coast of Africa, home to Somalia, is known as the Horn of Africa. Somalia runs east along the Gulf of Aden, where four percent of the world's oil is moved each day, and then southward along the coast, jutting out into the Indian Ocean in a domestic region known as Puntland. Finally, its border falls south past the war-torn lands surrounding the latent capital Mogadishu. " Somalia is a country known for both its bitter internal struggle between moderates and

3. Int'l Chamber of Commerce, Commercial Crime Services, IMB Reports Unprecedented Rise in Maritime Hijackings, Jan. 16, 2009, http://www.icccs.org/index. php?option=com_content\&view=article\&id=332:imb-reports-unprecedented-rise-inmaritime-hijackings\&catid=60:news\&Itemid=51 [hereinafter CCS IMB].

4. Id.

5. Int'l Chamber of Commerce, Commercial Crime Services, 2009 Worldwide Piracy Figures Surpass 400, Jan. 14, 2010, http://www.icccs.org/index.php?option=com_content\& view=article\&id=385:2009-worldwide-piracy-figures-surpass400\&catid=60:news\& Itemid=51 [hereinafter CCS 2009 Report].

6. CCS IMB, supra note 3 .

7. Id.

8. Id.

9. Id.

10. Int'l Chamber of Commerce, Commercial Crime Services, IMB Live Piracy Map 2009, http://www.icccs.org/index.php?option=com_fabrik\&view-visualization\&controller= visualization.googlemap\&Itemid=219 (last visited Feb. 15, 2010).

11. See Central InTelligence Agency, The World FACTBOoK (2009), available at https://www.cia.gov/library/publications/the-world-factbook/geos/so.html (last visited Feb. 18, 2010) [hereinafter CIA WORLD FACTBOOK]; Ellen Knickmeyer, 100 Hostages Held by Somali Pirates, WASH. POST, Sep. 12, 2008, at A11. 
extremists and its lack of external validity. Somalia's failure on the international stage results from the country's inability to maintain neither an operative central government since 1991, nor a central bank, meaning there is no functioning economy. ${ }^{12}$ Inflation is impossible to calculate because businesses print money, and there are vast disparities in regional economies. ${ }^{13}$ According to recent estimates, the life expectancy rate for Somalis is under fifty years, and the gross domestic product per capita sits around US $\$ 600 .^{14}$

Statistics such as these are important for understanding the motivations of those committing the attacks identified by the IMB. In working to recognize the consequences of piracy and the industry's influence on both the domestic and global economies, it is necessary to first examine the political and economic status of the country contributing to piracy. As with most international or domestic developments, a proper understanding of the potential catalysts of a particular situation allows one to understand the logical implications that may result. In other words, a meta-analysis of recent events that prove this trend in maritime piracy may create a method for forecasting future events and for determining options that may potentially curb this growing, illicit industry.

Part One of this Note will examine the contemporary trends in maritime piracy. Part Two will discuss an analysis of the political and economic factors that may contribute to these trends. Part Three moves further into a conversation about the motivations for piracy based on international pressure, an unbalanced power structure, and unaccommodating maritime law. Part Four finishes with a look into the global implications and foreseeable difficulties the world may be facing, largely as a result of international irresponsibility.

\section{CONTEMPORARY TRENDS IN MARITIME PIRACY}

As previously noted, 2009 marked the contemporary pinnacle in maritime piracy. The figures for 2009 are higher than all other figures for hijacked vessels since the inception of the IMB Piracy Reporting Centre. ${ }^{15}$ Of the 406 reported incidents of piracy against ships, 153 vessels were boarded, forty-nine were hijacked, and 120 were fired upon, compared to only forty-six fired upon in 2008. ${ }^{16}$ The significance of this increase is that it suggests pirates have greater access to weapons,

12. See CIA WORLD FACTBOOK, supra note 11.

13. Id.

14. Id.

15. See CCS 2009 Report, supra note 5.

16. Id.; CCS IMB, supra note 3. 
enabling more violent attacks.

The considerable growth in the attacks reported by the IMB is attributable to the Gulf of Aden region, where in 2009, 217 attacks were reported either within the Gulf or off the coast of Somalia, compared to 111 in $2008 .^{17}$ In 2008, Nigeria ranked second, with forty attacks reported, and the IMB estimates that there are approximately one hundred more unconfirmed incidents that have occurred in the area, where under-reporting remains a major concern. ${ }^{18}$ This trend continued in Nigeria during 2009, with twenty-eight confirmed attacks and another thirty estimated unreported. ${ }^{19}$ These drastic increases around Africa have come at a time when other areas already known for incidents of piracy have experienced significant declines. ${ }^{20}$ For example, Indonesia reported only twenty-eight incidents in 2008, down from 121 in 2003, and within the Malacca Straits the number was also reduced. ${ }^{21}$

These trends reflect the international character of maritime piracy. Piracy in Southeast Asia has seen a steady decline since the increased involvement of more developed nations such as Japan and China, which assumed more active roles in order to protect their international industries. ${ }^{22}$ Such involvement, combined with the increased number of attacks in areas lacking a strong central government betrays a now obvious feature of the pirating industry. It can subsist in regions where there is populist support and lack of a sound governmental foundation. However, this analysis makes combating piracy sound deceptively simple and fails to acknowledge the realities of international diplomacy.

\section{PIRACY IN SOMALIA}

Piracy is the fastest growing industry in Somalia and is projected to have replaced agriculture and fishing as the country's largest generator of revenue. ${ }^{23}$ Of course, identifying it as such is misrepresenting the truth in a country that maintains no central bank and that deals in corruption. ${ }^{24}$ To suggest that piracy is in fact an industry, as it is labeled

17. CCS 2009 Report, supra note 5; CCS IMB, supra note 3 .

18. CCS IMB, supra note 3 .

19. CCS 2009 Report, supra note 5.

20. CCS IMB, supra note 3.

21. Id.

22. Ian Barclay, Private Sector Helps to Ease Piracy Fears in Malacca Strait: But State Help Is Still Crucial in the Waters, LLOYD'S LIST, July 4, 2006, at 4.

23. David Axe, No Quick Solutions to Pirate Crisis, WoRLD PoL. REv., Oct. 6, 2008, http:/www.worldpoliticsreview.com/article.aspx?id=2744.

24. Mohamed Olad Hassan \& Elizabeth Kennedy, Pirates' Ransom Helping Somalian Towns Boom, SEATTLE TLMES, Nov. 20, 2008, available at http://seattletimes. nwsource.com/html/nationworld/2008413082_pirateboom20.html. 
in both this Note and in other documents, ignores the fact that a country must first be industrial in order to have identifiable primary and secondary industries. Ignoring this obvious nominal defect, piracy may be seen as an industry because it has the potential to accomplish what most legal industries in countries with robust economies can-it provides goods and services for people who, in this particular case, have severely limited access to them. In order to better understand this idea, it is necessary to first discuss recent economic and political trends in Somalia, followed by an examination of how these two sectors have worked in conjunction to encourage piracy in the region.

\section{A. Political Destabilization and Stagnation}

In 1991 the authoritarian socialist regime that had governed Somalia since a coup in 1969 collapsed..$^{25}$ In May of that same year, northern clans formed what they declared to be an independent Republic of Somaliland, which has not been formally recognized by any government. ${ }^{26}$ Following suit, three regions in the northeast formed the self-governing and self-declared autonomous state of Puntland in $1998 .^{27}$ Within Puntland are the cities Boosaaso and Eyl, both known for their links with Somali piracy. ${ }^{28}$ In 1993 , the United Nations (U.N.) began a two-year humanitarian effort to alleviate famine, targeting the south where the Somali capital Mogadishu is located. But by the time the U.N. withdrew in 1995, order had not yet been restored, and the U.N. had suffered significant casualties. ${ }^{29}$

More recently, in 2004 an interim government known as the Somalia Transitional Federal Institution (TFI) was created in the south. ${ }^{30}$ In 2006, the Council of Islamic Courts (CIC), a group of Islamic court militias, took control of Mogadishu. ${ }^{31}$ The CIC then continued its military expansion through the south and threatened to overthrow the Transitional Federal Government, located west of the capitol in Baidoa. $^{32}$ Yet in December 2006, Ethiopian forces assisting TFI moved into the region and intervened, resulting in the collapse of the CIC. ${ }^{33}$ However, steady resistance from Islamic extremist groups has

\footnotetext{
25. CIA WORLD FACTBOOK, supra note 11.

26. Id.

27. $I d$.

28. Id.

29. Id.

30. Id

31. Id.

32. $I d$.

33. Id.
} 
continued throughout the country, leading to political stagnation. ${ }^{34}$

The political situation in Somalia has led to an ideological divergence among those in charge about the status of the nation's government. As Islamic insurgents drew closer to the nation's capital, the now-former president of the transition government, Abdullahi Yusuf Ahmad, stated that the government could collapse. ${ }^{35}$ Prime Minister Nur Hassan Hussein did not share the same view in late 2008 when he stated that the government was moving toward stabilizing the country with the help of the U.N. and Ethiopian forces. ${ }^{36}$ However, on January 31, 2009, Moderate Islamist leader Sheikh Sharif Sheekh Ahmed became the new President of Somalia, only days after Ethiopian troops withdrew from Somalia and rebel forces launched an attack on the parliament building and presidential palace in Baidoa, leaving only the presidential palace in Mogadishu under government control. ${ }^{37}$ The Somali Civil War has continued throughout the south of the country during 2009.

This political dysfunction, running for nearly two decades, has coincided with instability in the nation's economy, which may only be characterized as informal at best. Most recently, Ahmedou OuldAbdallah, the Secretary-General's Special Representative, stated that "the crisis in Somalia [is] no longer local or even regional, but a global one that could no longer be ignored." 38

\section{B. Economic Informality and Degradation}

The United States Central Intelligence Agency (CIA) reports that "[d]espite the lack of effective national governance, Somalia has maintained a healthy informal economy, largely based on livestock, remittance/money transfer companies, and telecommunications." ${ }^{39}$ In fact, this statement denies the degree of the economic hardship in Somalia, one of the United Nations fifty "least developed countries." Agriculture is identified as the most important sector in Somalia, and

34. Id.

35. Edmund Sanders, The President Is to Blame for Somalia's Woes, Premier Says, L.A. Times, Nov. 19, 2008, at 4.

36. Id.

37. CNN.com, New Somali President Sworn in Amid Upheaval (Jan. 31, 2009), http://www.cnn.com/2009/WORLD/africa/01/31/somalia.election.president/index.html.

38. Press Release, Security Council, Secretary-General's Special Representative, Briefing Security Council, Calls Somalia 'Global Crisis' That Can No Longer Be Ignored, U.N. Doc. SC/9844 (Jan. 14, 2010).

39. CIA WORLD FACTBOOK, supra note 11.

40. U.N. Office of the High Representative for the Least Developed Countries: Somalia, http://www.unohrlls.org/en/orphan/136/ (last visited Feb. 25, 2010). 
the U.N. has concluded that economic life has continued in the nation during two decades of political chaos because much of the economic activity in Somalia is local and can therefore be protected. ${ }^{41}$ Livestock is the primary export in Somalia, but a recent ban by Saudi Arabia on Somali livestock has caused a severe decline in the industry. ${ }^{42}$ Also, Somalia's industrial sector has reportedly been looted and sold for scrap metal according to both the U.N. and CIA. ${ }^{43}$

The claim that Somalia has maintained a healthy informal economy could not be further from the truth. UNICEF reports the average annual growth rate of GDP per capita between 1970 and 1990 to be $-0.9 \% .^{44}$ The statistic is unavailable after 1990 because there is no longer an appropriate method to obtain this type of data. ${ }^{45}$ For 2008, the United Nations Office for the Coordination of Humanitarian Affairs reported a total of almost $\$ 616$ million committed or contributed to help the Somali economic crisis and another $\$ 70$ million pledged. ${ }^{46}$ In 2009 , almost $\$ 622$ million was committed or contributed with another $\$ 40.5$ million pledged. ${ }^{47}$

\section{Politics and the Economy: The Effect on the Fishing Industry of Coastal Somalia}

The combination of a failed internal economy and lack of an adequate governance structure has had a unique effect on one particular sector of the nation's coastal economy. The domestic fishing industry has declined over much of the last two decades, and this may have directly contributed to the rise in piracy off the coast of Somalia. ${ }^{48}$

In 1994, only three years after the collapse of the Somali government, UNCLOS entered into force, thereby creating a zone for coastal nations to possess the exclusive rights to the natural resources

41. Id.

42. Id.

43. Id.

44. UNICEF, Somalia Statistics, http://www.unicef.org/infobycountry/somalia statistics.html (last visited Feb. 18, 2010).

45. Id.

46. ReliefWeb, Appeals \& Funding, http://ocha.unog.ch/fts/pageloader.aspx?page= searchreporting_display\&CQ=cq020209001620hQxNcuXsbg\&orderby=USD_pledg\&show Details= (last visited Feb. 18, 2010).

47. ReliefWeb, Appeals \& Funding, Somalia: Funding Received 2009, http://reliefweb.int/rw/fts.nsf/doc105? OpenForm\&rc=1\&cc=som\&yr=2009 (last visited Feb. 18, 2010).

48. Jeffrey Gettleman, Pirates Tell Their Side: They Only Want Money, N. Y. TIMES, Oct. 1, 2008, at A6. 
found therein. ${ }^{49}$ This adoption established a limited territory for fishermen and confined them to their national waters. ${ }^{50}$ Confinement created an increase in competition within these newly defined national boundaries, resulting in stock depletion throughout Somalia's tuna-rich waters. ${ }^{51}$ Yet stock depletion was not merely the direct result of domestic over-fishing off coastal Somalia. ${ }^{52}$

After the collapse of the domestic government, foreign ships moved into the region and began to illegally fish in Somali territory. ${ }^{53}$ The absence of a functional method for enforcement of maritime fishing law, due to a non-functioning government and complete lack of naval force, meant that fishing vessels from Europe and Asia were able to deplete the nation's fisheries, which some Somalis believe to be the reason for poverty and social decay in their coastal towns. ${ }^{54}$ The U.N. substantiated this claim in 2005 when it estimated that approximately 700 unlicensed foreign vessels were fishing in Somali waters. ${ }^{55}$ As a result, Somali fishermen were reportedly forced to take matters into their own hands. ${ }^{56}$ They armed themselves and began to act as vigilantes, confronting illegal commercial fleets, demanding they pay taxes, and attempting to drive the vessels from their territory. ${ }^{57}$

If tuna stock depletion in Somalia is the result of negative foreign influence, then it is necessary to point out the circular pattern into which this power dynamic has now evolved. Some pirates claim that they turned to hijacking as a method to impede foreign vessels trying to destroy their fishing boats and equipment and to inhibit illegal fishing. ${ }^{58}$ Now, according to recent statistics, it appears that the Indian Ocean tuna industry has been hurt by the piracy it may have helped cause. ${ }^{59}$ Tuna catches in the southwestern Indian Ocean fell as much as thirty percent over 2008, and this suggests a real threat to an industry that is worth over $\$ 6$ billion. ${ }^{60}$ This sharp decline has not been attributed

49. UNCLOS, supra note 1, arts. 55-56.

50. Sean Kane, Fishing for the Motives that Lie Behind Piracy; Attacks on Vessels Can Often Be Attributed to Social Deprivation in Coastal Regions, LLOYD'S LIST, Mar. 5, 2008, at 19.

51. Id.

52. Id.

53. Id.

54. Id.

55. Kane, supra note 50.

56. Gettleman, supra note 48.

57. Kane, supra note $\mathbf{5 0 .}$

58. Gettleman, supra note 48 .

59. See Richard Lough, Somali Pirates Threaten Indian Ocean Tuna Industry, REUTERS, Jan. 22, 2009, http://af.reuters.com/article/investingNews/idAFJOE50L09 S20090122.

60. Id. 
entirely to piracy on the Horn of Africa, but the head of the Indian Ocean Tuna Commission believes that countries such as France and Spain were forced to move their fleets farther east and therefore caught only half of their total from August to November $2007 .^{61}$

Illegal international commercial fishing along the coast of Somalia has resulted in stock depletion, which in turn forced local fishermen to adapt to the economic crisis by utilizing other methods to either drive out the competition or capitalize on their participation. In turn, this has caused pressure on a healthy international industry that, in this case, was the product of stronger nations capitalizing on the incapacity of another.

As previously noted, this international dysfunction is a reflection of the danger of globalization and the exploitation of an unfair international power dynamic. Rather than protect industry and domestic resources, the reality of UNCLOS is that its functionality is dependent on the strength of the state it purports to protect. The international community is failing to self-regulate by ignoring evidence suggesting that its members are taking advantage of a collapsed state that has no ability to enforce international law. Illegal commercial fishing fleets are able to exploit the domestic natural resources of a country without legal ramifications, forcing the local communities to take matters into their own hands. Furthermore, the legal irresponsibility of the international community has encouraged a domestic population to resort to illicit means to satisfy basic needs, and now the international community is essentially drowning in the very waters it attempted to protect.

This does not mean that UNCLOS fails to account for illegal activities of signatory states in a coastal state's exclusive economic zones. Article 58 asserts that "states shall have due regard to the rights and duties of the coastal state and shall comply with the laws and regulations adopted by the coastal State." ${ }^{62}$ However, Article 220 then discusses the enforcement of UNCLOS by coastal States, enabling these States to exercise enforcement within their exclusive economic zone or territorial waters. ${ }^{63}$ Yet this assumes that a coastal State has the ability to police its own territory with a functional navy or coast guard. In other words, in a situation where this is not a reality, as in Somalia, the State is left to hope that the commercial industries of other States choose not to illegally exploit available resources, although there are no legal or political repercussions if they do. Thus far, the only repercussions are the piracy attacks carried out by armed groups.

61. Id.

62. UNCLOS, supra note 1, art. 58.

63. Id. art. 220. 
As a result of the conflict, the U.N. adopted Security Council Resolution 1851 to create potential solutions to this problem and right the wreck, so to speak. ${ }^{64}$ Yet, from the outside looking in, it is hard to reconcile this push for the use of potentially violent force as an appropriate method to discourage any further exacerbation of an already rather uncontrollable situation. Instead this may in fact force the theoretical "balloon effect" that seems to be in play when applying pressure to an illegal industry that results from unalterable poverty, simply causing the same illegal industry to emerge elsewhere. In fact, this may already be happening on the other side of the continent-an idea that will be further explored in Part Four.

\section{CAN'T GET NO (NEEDS) SATISFACTION: CAN WE RIGHT THIS WRONG?}

The facts and patterns identified thus far lead to a conversation regarding a struggle for power resulting from alleged international transgressions. Therefore, this conversation must also focus on the question of whether a consequence of this struggle-piracy-is a justifiable result. While the purpose of this Note is not to justify piracy, viewing it from this alternate perspective identifies a difficult moral conundrum, and evaluating it may actually assist in finding solutions to diplomatically combat the recent plague of piracy. Although determining whether piracy is justifiable may be an easy question to answer from a legal-and in most cases moral-perspective because it pits law-breaking pirates against those diligently defending the industry and travel of the developed world, there is a different way of viewing the issue that makes identifying an answer more complex. An analysis of the conflict between the effort to satisfy basic needs in underdeveloped nations and the pursuit of secondary interests by developed nations, which maintain stronger positions of power on the international stage, blurs the line between right and wrong for those involved in piracy. In simpler terms, this conflict can be identified as one of primary concerns, such as obtaining food, shelter, and clothing, versus secondary concerns, such as promoting industrial development, transportation, and international trade.

The reality of increasing globalization is that these two very different interests exist alongside one another and in a much more consistently intimate way than ever before. Developed and underdeveloped nations are constantly in contact for a wide variety of reasons. Some are legal, such as enforcement of human rights laws, and

64. S.C. Res. 1851, ๆ 1, U.N. Doc. S/RES/1851 (Dec. 16, 2008). 
others are non-legal, ranging from humanitarian aid to border warfare.

Applying the analysis to the case of maritime piracy around the Horn of Africa portrays the polarization between developed and underdeveloped nations that engenders the justification conversation. On one side, an identifiable concern could be whether an individual will be able to eat on any given day, and on the other, a concern may be the destabilization of the global economy, exemplified in part by the disruption of major oil shipments through the Gulf of Aden. Further exploration of these issues requires a return to Somalia.

\section{A. Reformation of the Somali Coastal Economy: The Pirate Side of Life}

Along with the recent increase in pirate attacks comes a number of articles portraying pirates in an exaggerated manner-a throwback to the days of yellow journalism-emphasizing this "glamorous" return to barbarism. However, among the embellished stories of those who report on the talismanic identity of these "Robin Hood"-type pirates, there lies a significant truth about the effect of piracy on the domestic economy of Somalia. Piracy as an industry may actually be economically benefiting the Somali people, and towns along the coast of Puntland are becoming almost as newsworthy as the pirates who reside in them.

Harardhere, Boosaaso, and Eyl are villages that have benefited from a pirate economy. ${ }^{65}$ In Eyl, villagers report that more shops are opening, including Internet cafes and telephone stores, and that business is good. ${ }^{66}$ Business owners believe that pirates depend on them and that they are benefiting from the businesses in town. ${ }^{67}$ When pirates hijack a ship, it is then moved from deeper water to the coast so that the pirates may resupply, which they come ashore to do almost daily. ${ }^{68}$ In some cases, store owners even set up layaway plans for them, anticipating the influx of money from ransom. ${ }^{69}$ Residents seem to care very little about where the money comes from and whether it is obtained legally or illegally, as long as it keeps food on the table. ${ }^{70}$ Even twenty-four-hour electricity, once an unknown commodity in this part of the country, has been made available where large houses and nice cars are becoming increasingly visible. ${ }^{71}$ Yet others believe that Eyl may not be benefiting and suggest that the money stays with the pirates, who merely use the

\footnotetext{
65. Hassan \& Kennedy, supra note 24

66. Id.

67. Id.

68. Id.

69. Id.

70. Id.

71. Id.
} 
town as a port before returning to their native villages. ${ }^{72}$

In Boosaaso a similar economic upturn has taken place, though it has come at a price. The economy of the village has crashed, and inflation has increased due to a lack of available work that is a result of a decline in shipping traffic. ${ }^{73}$ Yet there is also new construction in the city. ${ }^{74}$ A new section of town is developing called New Boosaaso. ${ }^{75}$ Here, as in Eyl, houses are being constructed which cost several hundred thousand dollars and have been linked to pirate money. ${ }^{76}$

The statistics are suggestive and so are the accusations from coastal residents. The United Nations Monitoring Group on Somalia reported in December 2008 that ransom payments were to exceed fifty million dollars for that year and that the total budget for Puntland is only approximately twenty percent of projected piracy revenue over the same period. ${ }^{77}$ Members of the state government are accused of working with pirates, including the former president of Puntland, whose nephew was detained by Somaliland officials while carrying US $\$ 22,000$ in cash. $^{78}$ The allegations against members of the Puntland administration are well substantiated according to the U.N. Monitoring Group, which reported that several officials in Puntland were fired for involvement in piracy, and that the mayor of Eyl previously alleged the complicity of ministers and police officials in piracy. ${ }^{79}$

The fluidity in the piracy industry is one of the primary factors indicative of its potential to bolster the coastal economy. Pirates are usually young men in their twenties who are illiterate, unable to find work, and willing to die trying to earn money ${ }^{80}$ However, many of these men, upon involving themselves with one or two hijackings and receiving cash payments for their services, are eager to retire. ${ }^{81}$ This suggests that there is ample opportunity to become involved in piracy,

72. Shashank Bengali, Forget Depp: Somali Pirates Risk All for Riches, Women, Christian SCIENCE MONITOR, Dec. 19, 2008, available at http://www.csmonitor. com/2008/1219/p25s41-woaf.html.

73. Jeffrey Gettleman, Somalia's Pirates Flourish in a Lawless Nation, N.Y. TIMES, Oct. 31,2008 , at $\mathrm{A} 1$.

74. Id.

75. Id.

76. Id.

77. U.N. Sec. Council, Monitoring Group on Somalia, Report of the Monitoring Group on Somalia Pursuant to Security Council Resolution 1811, II 127-28, U.N. Doc. S/2008/769 (Dec. 10, 2008) [hereinafter UNSC Report].

78. Gettleman, supra note 48.

79. UNSC Report, supra note 77, \ 141.

80. Jamal Osma, 'We Are Hungry. There Is No Government, No Economy, So It Is a Good Way to Earn Money,' THE TIMES (London), Dec. 12, 2008, at 54, available at http://www.timesonline.co.uk/tol/news/.

81. UNSC Report, supra note 77, ๆ 131. 
and the numbers are reflective of this fact. The total number of pirates estimated to be operating in the waters off Somalia's coast is now between 1,000 and 1,500. Some fear the payment of ransom is only encouraging more to join. ${ }^{82}$ The potential to earn US $\$ 1-2$ million per hijacked ship is hard to pass up for those who have nothing else to rely on for income. ${ }^{83}$ It is believed that piracy contributes to the local economy and, while it is evident that Somali piracy is driven by a determination for needs satisfaction and has achieved relative success in the process, the world perspective on piracy reflects a far different reality.

\section{B. Implications for a Global Society: The International Economic Perspective on Piracy}

Piracy has placed a stranglehold on the shipping industry throughout the Gulf of Aden, and the global implications from the recent surge are already visible. Throughout the Indian and Pacific Oceans, it is estimated that piracy costs the shipping industry between thirteen and fifteen billion dollars. ${ }^{84}$ Over the last year, insurance premiums have spiked, rising from approximately $\$ 900$ at the beginning of 2008 to $\$ 12,000$ by November 2008, with another sixty percent increase estimated between November and December. ${ }^{85}$ The shipping industry has been forced to adapt by finding other routes, thereby greatly increasing costs due to, among other things, the need for security. ${ }^{86}$ These increased costs take their economic toll on the consumer when they are reflected in the final price of the shipped goods. $^{87}$

Although each day more than three million barrels of oil pass through the Gulf of Aden, accounting for four percent of the world's oil transportation, the effects of piracy are not limited to this industry. ${ }^{88}$ There are also serious humanitarian consequences that are influencing

82. Id. I 124; see also Bengali, supra note 72.

83. Phillip Hafner, Piracy Boosts Somali Economy, GLOBAL ENVISION, Apr. 27, 2009, http://www.globalenvision.org/2009/04/13/piracy-boosts-somali-economy.

84. James Kraska \& Brian Wilson, Fighting Pirates: The Pen and the Sword, 25 WORLD POL'Y J., Winter 2008/09, at 41, 43.

85. Hardev Kaur, Pillaging Pirates Pile Gloom on World Trade, New Straits Ttmes (Malay.), Nov. 28, 2008, at 25.

86. Id.

87. Id.

88. James Carroll, Op-Ed., What the Pirates Say, Boston GloBe, Nov. 24, 2008, available at http://www.boston.com/bostonglobe/editorial_opinion/oped/articles/2008/ 11/24/what_the_pirates_say/. 
the international agenda, and also eroding Somalia domestically. ${ }^{89}$ Nongovernmental organizations with the primary focus of delivering aid to the more than 2.5 million people in need of food in Somalia are having their efforts curbed by piracy. ${ }^{90}$ In December 2004 it was reported that the U.N.'s World Food Programme was closing its maritime supply lines due to piracy, significantly driving up the cost of delivering food aid and causing food aid stocks to reach an all time low. ${ }^{91}$ The lack of international access to many Somalis as a result of piracy can be considered an international dilemma and another of the secondary interests of the international community.

One does not have to look farther than Somalia's neighbor to the south, Kenya, to substantiate this economic claim. In November 2008, the Daily Nation, a Kenyan newspaper, released a report stating that Somali piracy is an economic emergency that is strangling Kenya at a time when there is already financial difficulty. ${ }^{92}$ The Kenyan treasury has already been depleted by security operations that seek to prevent problems such as illegal arms transfers and illegal immigration into the country. ${ }^{93}$ Piracy has complicated this problem because Kenya produces much of its wealth using its maritime industry and there is great risk that the transportation sector, which provides twelve percent of the country's GDP, will be greatly diminished. ${ }^{94}$

Other pressure on the regional economy comes from higher insurance rates and higher shipping costs. ${ }^{95}$ Egypt also reported in November 2008 that diverting shipments around the Cape of Good Hope would only increase costs and slow down transport times. ${ }^{96}$ The international implications are clear: Somali piracy has a direct effect on industry both within the region and beyond, and the pirates' interest in self-preservation is burdening the economic interests of the international community.

89. UNSC Report, supra note 77, ๆ 129.

90. Id.

91. Afrol News, Somalia Pirates Complicate Food Aid Provision (Dec. 5, 2004), http://www.afrol.com/articles/17547.

92. Editorial, Somali Situation Threatens Regional Economies, DaILY NaTION, Nov. 22, 2008, available at http://www.nation.co.ke/oped/ Editorial//440804/493782/-/qjq6nkz/. /index.html.

93. Id.

94. Id.

95. Id.

96. Sean Kane, Political Will Still a Hurdle in Anti-Piracy Campaign; Economic Woes Could Be Incentive for Action, LLOYD's LisT, Nov. 5, 2008, at 14. 


\section{The Ideological Intersection Between Primary Domestic and Secondary Global Interests}

The purpose of the accumulation of this information is to suggest that there is more to this story than the decimation of the Gulf of Aden's shipping industry. The satisfaction of basic needs-the need to eat, the need for electricity, or the need for some form of economic stabilization that will fight back inflation and devaluation of goods and services-is the driving force behind this criminal enterprise. Identifying this root shows how international conflict may evolve where a practical, though unlawful, solution to basic needs satisfaction intersects with the secondary interests of the modernized world.

Admittedly, rationalizing future conformity to the rule of law for individuals that are acting illegally seems ineffective in this situation because there is nothing to bargain over if neither side is able to identify an equally successful second option to satisfy basic needs. However, the purpose of this Note is not to advocate the use of illegal tactics to satisfy primary needs in an undeveloped nation, but rather to explore the motivations behind the trend. There is no support to posit that an illegal action chosen based on a clear lack of legal alternatives is justifiable. Yet this consideration helps illuminate the fact that it is the responsibility of the international community to realize that this is only nominally-elective behavior, and to readjust this populist mentality from the inside out, not from external pressure. In particularly dire situations, motivation is arguably derived from the opportunity to achieve some gain through whatever means may be necessary, and this may include breaking the law, whether international or domestic. In this case, there are few other means available, and they are both unreliable and possibly less effective. Though the pirates may be creating more internal strife by exacerbating their domestic problems, they are also responding to those problems which currently exist.

The goal in portraying Somali coastal society as a benefactor of, and beneficiary from, piracy is to depict this dichotomy as something that is more than a disagreement over morality. Piracy is a domestic response to an unfair power dynamic that has only recently played out in this region to the detriment of the rest of the world. Its global economic implications are forcing the international community to acknowledge the existence of a problem that has been ignored for years. To this effect, piracy may be actually encouraging international actions which, if undertaken, could lead to the stabilization of the region. The core of the problem is lack of access to items necessary for satisfying basic needs, and the only way to derail the illicit industry that is fulfilling these needs may be to replace it with a legal method that is more efficient and 
effective than piracy.

The reality is that piracy is an unjustifiable response to a domestic crisis. Rather than accomplishing the good some believe it does, the domestic consequence is the empowerment of a dangerous and desperate group of people who are only motivated by their own self interests, not the primary needs of others. Perhaps money is not being invested in proper domestic industries but rather reinvested in an illicit one, or it is being sent abroad to expatriates or private financiers. Surely, those who feel the global ripple of detrimental effects resulting from the actions of these buccaneers are not necessarily the catalysts of piracy. They do not encourage the radicalism and infighting that has crippled the nation for nearly two decades. Primarily it is the Somalis who cause their own domestic political strife and suffer the economic consequences.

\section{Eradicating Piracy Through Internal Efforts and Humanitarian Aid}

Although the lack of domestic control of crime is well documented, it appears that along with the increase in piracy there is also some semblance of a negative domestic reaction to the industry by the Somali people. Within communities where an influx of capital from piracy is present, there are also grassroots militias forming to ward off pirates, mainly because of the country's strict adherence to Islam. ${ }^{97}$ Puntland's new President Abdirahman Mohamed Mohamud stated that "pirates are spoiling our society" and that he intends to "crush them." 98 Indeed some of Puntland's resident pirates have made clear that they are willing to quit if they are able to find regular jobs and protection against illegal fishing and dumping. ${ }^{99}$ Further, it is reported that Puntland officials have acknowledged that Somalia may ultimately benefit from the increased exposure that piracy has brought to Somalia, as previously posited in this Note. ${ }^{100}$

Between 2008 and 2013, the European Commission and its Member States have pledged more than $£ 215$ million in aid for the domestic development of Somalia ${ }^{101}$ In 2009 , the U.S. government provided more

97. Jeffrey Gettleman, For Somali Pirates, Worst Enemy May Be on Shore, N.Y. TIMES, May 9, 2009, at A1.

98. Id.

99. Id.

100. Id.

101. Battling Modern-Day Piracy off the Coast of Somalia: The European Union's Operation Atalanta, EU INSIGHT (Delegation of the Eur. Comm'n to the U.S., Wash. D.C.), Aug. 2009, http://www.eurunion.org/News/eunewsletters/EUInsight/2009/EUInsightPiracy-8-09.pdf. 
than $\$ 150$ million for humanitarian assistance in Somalia. ${ }^{102}$ These numbers, in conjunction with reports by local government officials, suggest that the piracy industry may be ready to implode at the hands of domestic stabilization through the increased provision of humanitarian aid rather than through the use of international force.

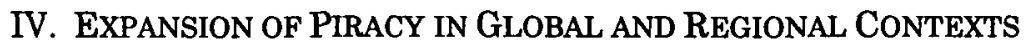

Although the economic implications of contemporary maritime piracy were already explored in the context of identifying the ideological conflict between primary domestic and secondary international interests, the issue must be revisited, this time in order to discuss the compositional quality of the industry and the specific regional influence resulting from maritime piracy off the coast of Somalia.

\section{A. The Structural Composition of Somali Piracy: From Financing to Hijacking}

There are two main networks of pirates operating off the coast of the Horn of Africa, and despite reports suggesting otherwise, they are loosely organized and poorly trained. ${ }^{103}$ The first network is located in Puntland, based mainly in the Eyl district, while the other is located in Central Somalia. ${ }^{104}$ To some extent, these two networks cooperate and coordinate with one another, and the organizations are guided largely by the principles of private enterprise. ${ }^{105}$ The security sector in Puntland is relatively weak, and there is simply no capacity for law enforcement in Central Somalia. ${ }^{106}$ Both private financiers and other prominent business organizations advance the startup money for the pirate groups. ${ }^{107}$ Aside from cash, these funders also provide assistance in the form of boats, fuel, arms, and communication equipment. ${ }^{108}$

The second phase of the piracy operation begins with the seizure of a targeted vessel. ${ }^{109}$ Once a vessel is seized, it is the financier's job to find a sponsor who is willing to bankroll the cost of the operation, which

102. USAID, OFFICE OF U.S. FOREIGN DISASTER ASSISTANCE, SOMALIA-Complex EMERGENCY (2010), http://www.usaid.gov/our_work/humanitarian_assistance/disaster_ assistance/countries/somalia/template/fs_sr/fy2010/somalia_ce_sr02_2-03-2009.pdf.

103. UNSC Report, supra note 77, I 131.

104. Id. \ 132 .

105. Id. ग 136.

106. Id. I 127.

107. Id. \ 136.

108. Id.

109. Id. T 139. 
will eventually be paid back through a share of the ransom. ${ }^{110}$ The vessel is then taken to a coastal port, an attribute for which the village of Eyl has made its namesake. Once in port, a ground team awaiting the arrival takes care of the supplies and pays for local protection of those on board the vessel. ${ }^{111}$ This indicates that there is some form of corrupt political acquiescence in play, and the U.N. Monitoring Group reported that senior government officials are among those involved. ${ }^{112}$

After negotiations, a ransom is paid in cash to those who successfully influence the foreign entity that owns the vessel. ${ }^{113}$ Distribution is flexibly scaled but is reported to resemble the following: maritime militia, ten percent; ground militia, ten percent; local community, ten percent; financier, twenty percent; sponsor, thirty percent. ${ }^{114}$ These numbers suggest that at least half of the total ransom paid goes to those putting up the money to finance the operation, with relatively low risk compared to the incredibly high reward that may be obtained.

Somali piracy has also been linked to other criminal operations within the region, suggesting that foreign financing may be a reality. Arms and human trafficking have both been linked to piracy in the Gulf of Aden and one group within Puntland allegedly uses the same boats that it uses for piracy to move refugees and economic migrants between Somalia and Yemen. ${ }^{115}$ The allegations of international funding and collaboration has brought increasing concern about the global reach of piracy.

\section{B. Regional and Global Expansion: The Niger Delta and Caribbean Connection}

One idea that has been shared in articles that are written on the subject of combating maritime piracy is that the success of Somali piracy may be contributing to its success elsewhere. Although this is not the primary focus of this Note, it is an idea that is important for any discussion on the topic. "The success of the pirates off Somalia is also a key factor behind the rise in attacks elsewhere, in areas such as Nigeria and South America." 116 Nowhere is this more evident than on the other

110. Id.

111. Id.

112. Id.

113. Id. ๆ 140.

114. Id.

115. Id. II 143-44.

116. Jerry Frank, Ransom for Seafarers Could Rocket to \$50m; Piracy Epidemic Will Fuel Huge Hike in Cover Costs, Says Hiscox, LLOYD's LIST, Sept. 15, 2008, at 4. 
side of the continent, within the Niger Delta region, where a lack of essential facilities combines with government corruption and resentment towards foreign companies. ${ }^{117}$ As previously mentioned, Nigeria accounts for the second-most-Somalia is first-reported incidents of piracy worldwide. ${ }^{118}$

Although piracy has surged in both countries at the same time, the motivations behind the movements diverge. Unlike Somalis, Nigerian pirates are believed to be politically, rather than financially, motivated. ${ }^{119}$ In fact, many of the attacks in Nigeria are legally classified as acts of terrorism or assault instead of piracy ${ }^{120}$ Hostage taking also seems to be reserved for ideological purposes in Nigeria, and is primarily limited to rebel groups acting against the oil industry. ${ }^{121}$ In Somalia, however, motives are not explicitly political and the lack of ideological demands encourages ship owners to pay ransom with the belief that payment will resolve the incident. ${ }^{122}$

The rise in piracy in Nigeria has revealed rifts between the State's pillars, including industry, local communities, and the government. ${ }^{123}$ Although there is still a functioning government, as is evident in Nigeria, this circumstance caters to the development of the maritime piracy industry. In April 2008, it was reported that many fishermen refused to work until the piracy threat diminished, which led to inflated food prices and a crippled government revenue stream. ${ }^{124}$ Local communities suffering as a result of the surge in piracy have called for government response, an option not available to their counterparts in the East. ${ }^{125}$

There is also speculation that piracy will move beyond its current continental establishment into South America. ${ }^{126}$ The Atlantic coast is reportedly poised to become a trading route of comparable significance to that of the Malacca Straits and the Gulf of Aden. ${ }^{127}$ Both Colombia

117. Abdulsamad Ali, Somalia; Maritime Body Wants U.N. to Move on Piracy off the Horn of Africa, (July 31, 2007), http://allafrica.com/stories/200707310625.html.

118. CCS IMB, supra note 3.

119. Sean Kane, Pirates Display Mixed Motives in Their Attacks; Crews Face Different Dilemmas in Nigeria and Somalia, LLOYD's LIST, Feb. 6, 2008, at 19.

120. Id.

121. Id.

122. Id.

123. Sean Kane, Threat to Safety Rises on Nigeria Piracy Inaction; Country's Commitment to Tackling the Issue Has Been Inconsistent, LLOYD's LIST, Apr. 2, 2008, at 15.

124. Id.

125. Id.

126. Sean Kane, Will Brazil Be the Next Somalia for Pirates?; Attacks Could Escalate from Petty Theft as Regional Trade Booms, LLoYD's LisT, Aug. 8, 2008, at 21.

127. Id. 
and Venezuela are major exporters of oil and gas, and Brazil, with an ever-strengthening economy and recent discovery of offshore energy reserves, is positioned to become a major player in the global export market. ${ }^{128}$ This means that a boom in the region's shipping industry may be in the foreseeable future, and along with it, the threat of maritime piracy. However, the government of Brazil is considerably more functional than those of the African countries that are plagued by piracy, and if the importance of this factor is realized, it may be enough to successfully deter piracy in a similar manner to China and Japan in the Malacca Straits. ${ }^{129}$

\section{CONCLUSION}

The surge in maritime piracy off the coast of Somalia is in many ways significant on a global scale, and the effects of this primarily domestic industry will continue to challenge the international community for some time. Though many have called for and taken action, there still exists a clear ideological divide between members of the international community, created by motivations that are best defined as primary needs satisfaction within underdeveloped nations on one side, and satisfaction of secondary interests in developed nations on the other. This conflict creates a moral conundrum for those seeking satisfaction of their basic needs, and begs the question of whether there exists a manageable way to deter piracy through a viable alternative, rather than simply using international force. What is also clear is that it is the responsibility of the international community to develop a timesensitive plan of action, rather than framing this as simply a domestic problem, or international industry stands to suffer at the hands of those it has contemporarily exploited.

128. Id.

129. Barclay, supra note 22. 
